\title{
Atlantic cod Gadus morhua save energy on stone reefs: implications for the attraction versus production debate in relation to reefs
}

Schwartzbach, Adina; Behrens, Jane; Svendsen, Jon Christian

Published in:

Marine Ecology - Progress Series

Link to article, DOI:

$10.3354 /$ meps 13192

Publication date:

2020

Document Version

Publisher's PDF, also known as Version of record

Link back to DTU Orbit

Citation (APA):

Schwartzbach, A., Behrens, J., \& Svendsen, J. C. (2020). Atlantic cod Gadus morhua save energy on stone reefs: implications for the attraction versus production debate in relation to reefs. Marine Ecology - Progress Series, 635, 81-87. https://doi.org/10.3354/meps13192

\section{General rights}

Copyright and moral rights for the publications made accessible in the public portal are retained by the authors and/or other copyright owners and it is a condition of accessing publications that users recognise and abide by the legal requirements associated with these rights.

- Users may download and print one copy of any publication from the public portal for the purpose of private study or research.

- You may not further distribute the material or use it for any profit-making activity or commercial gain

- You may freely distribute the URL identifying the publication in the public portal 


\title{
Atlantic cod Gadus morhua save energy on stone reefs: implications for the attraction versus production debate in relation to reefs
}

\author{
Adina Schwartzbach, Jane W. Behrens*, Jon C. Svendsen \\ National Institute of Aquatic Resources (DTU Aqua), Technical University of Denmark, 2800 Kgs. Lyngby, Denmark
}

\begin{abstract}
Reefs are structurally complex habitats that are degraded in numerous coastal areas. Structural complexity is often associated with elevated fish abundance, and recent studies have indicated that such structural complexity (e.g. reefs) not only acts as a fish aggregator, but also increases fish production. The objective of this study was to advance this knowledge by investigating if an underlying mechanism of the observed productivity is related to reduced metabolic rates (proxy for energy use) of fish in reef habitats. Using juvenile Atlantic cod Gadus morhua, we tested the hypothesis that fish energy use differs between fish occupying stone reef and sand bottom habitats. Metabolic rate $\left(\mathrm{MO}_{2}\right)$ was estimated using intermittent flow respirometry in simulated stone reef and sand bottom habitats over $24 \mathrm{~h}$. Results revealed that G. morhua in the stone reef habitat exhibited significantly reduced accumulated $\mathrm{MO}_{2}$ compared to G. morhua in the sand bottom habitat. Likewise, there was a tendency for lower mean standard metabolic rates of the fish in stone reefs, although this pattern was not statistically significant. There are many mechanisms that may underpin elevated productivity in structurally complex habitats such as reefs, including better access to shelter and increased food availability. Our study adds to these mechanisms by showing that G. morhua save energy when occupying stone reefs as compared to sandy bottoms, energy which may be allocated to somatic and gonadal growth.
\end{abstract}

KEY WORDS: Gadus morhua - Artificial reef · Fish production - Habitat - Marine restoration . Metabolic rate

Resale or republication not permitted without written consent of the publisher

\section{INTRODUCTION}

Anthropogenic impacts on coastal habitats are a global concern. Structurally complex habitats are degrading across many marine environments (Airoldi et al. 2008), which is caused by several factors, including trawl fisheries, resource extractions, coastal constructions and climate change (Thrush \& Dayton 2002, Lotze et al. 2006, De'ath et al. 2012). Reefs are considered habitats that provide structural complexity and are therefore specifically protected in many regions, including the European Union (The Council of the European Communities 2013) and Australia (Australian Government 1975). In addition, reefs are increasingly restored and used as management tools worldwide (Bohnsack \& Sutherland 1985, Nakamura 1985, Kristensen et al. 2017).

Based on the observation that artificial reefs, and habitats with structural complexity in general, attract and concentrate fish (Bohnsack \& Sutherland 1985, Ambrose \& Swarbrick 1989, Demartini et al. 1994), the 'attraction versus production' debate was initiated in the 1980s, addressing the question whether reefs act merely as fish aggregators, or if such complex habitats may also facilitate increased fish production (Bohnsack \& Sutherland 1985, Polovina 1989). It is increasingly becoming clear that reefs (both artificial and natural) contribute to overall fish production 
(Granneman \& Steele 2014, Smith et al. 2016, RoaUreta et al. 2019), yet the extent of the production increase and its underlying mechanisms remain unclear. A key question is whether specific habitats influence fish energy use and thereby the potential for investment into somatic growth or gonad production (Grossman et al. 1997).

Stone reefs provide high biodiversity (Lundsteen et al. 2008), and in temperate waters, these complex habitats often host gadoids, including Atlantic cod Gadus morhua (Dahl et al. 2016). Mature fish gather in areas with stone reefs before migrating to spawning grounds and use reefs as shelter (Dahl et al. 2016). Maturing G. morhua often respond favorably to stone reef restoration, further highlighting the importance of stone reefs fo relatively large G. morhua (Kristensen et al. 2017). Smaller conspecifics, however, also take advantage of structurally complex habitats such as reefs (Gotceitas \& Brown 1993, Tupper \& Boutilier 1995). Juvenile G. morhua are frequently preyed upon by larger fish and marine mammals, including harbour porpoise Phocoena phocoena, harp seal Pagophilus groenlandicus and grey seal Halichoerus grypus (Savenkoff et al. 2006, Ross et al. 2016). To avoid predation, G. morhua shelter within complex habitats, especially those consisting of boulders or cobble (Gotceitas \& Brown 1993, Gotceitas et al. 1995).

Fish metabolic rate is affected by various endogenous and exogenous factors, including shelter availability (Millidine et al. 2006). As such, measurements of fish metabolic rate provide a useful tool to understand the importance of various habitats (Norin et al. 2018). For most animals, oxygen consumption rate $\left(\mathrm{MO}_{2}\right)$ can be used as a proxy for aerobic metabolic rate and thus energy use (Nelson 2016). The basic maintenance requirement is measured as the minimum $\mathrm{MO}_{2}$ of a non-digesting, unstressed animal at rest and is known as the standard metabolic rate (SMR) (Priede 1985). Thus, other energy demands, including those related to swimming, digestion, reproduction and stress, are additional to SMR (Priede 1985). The presence of shelter is known to reduce stress, vigilance and alertness because shelters serve as protection from predators (Millidine et al. 2006). Thus, shelter in reefs could provide a metabolic benefit, but the hypothesis remains largely untested. If fish save energy when associated with reefs, the saved energy may be available for somatic growth and investment into reproduction.

Using juvenile G. morhua, we examined whether energy use is influenced by reef availability. Specifically, we used respirometry to test the hypothesis that energy use differs between G. morhua in simu- lated stone reef and sand bottom habitats. The findings are important for understanding the mechanisms that underpin the increased production of fish observed on reefs (Grossman et al. 1997, Baine 2001, Brickhill et al. 2005).

\section{MATERIALS AND METHODS}

Eleven juvenile Atlantic cod Gadus morhua (total length $24.7 \pm 0.9 \mathrm{~cm}$; body mass $251.2 \pm 20.5 \mathrm{~g}$; means $\pm \mathrm{SE}$ ) were caught using gillnets in the Isefjord in Denmark in March 2018. All fish were caught at the same location. Fish were held at the Technical University of Denmark (DTU Aqua) for a minimum of 1 mo prior to experimentation. Fish were tagged with individual PIT-tags and kept under the ambient light regime (May) in an aerated flow-through tank $(1 \times$ $2 \mathrm{~m}$; height $\times$ diameter) supplied with artificial saltwater (temperature: $10 \pm 0.2^{\circ} \mathrm{C}$; salinity: $10 \pm 1 \mathrm{psu}$ ). Fish were fed every other day with commercial pellets (Biomar, Efico Sigma 870).

The experimental set-up consisted of 2 similar grey experimental tanks $(52 \times 58 \times 94 \mathrm{~cm}$; height $\times$ width $\times$ length), each containing an identical respirometry chamber $(60 \times 11 \mathrm{~cm}$; length $\times$ diameter $)$ made of transparent acrylic glass tubing (Fig. 1). The 2 experimental tanks were situated in a room with restricted access, and the tanks were further shielded from the surroundings using curtains to minimize any disturbance.

Each experimental tank contained 2701 of flowthrough water from the same source as used for the holding tank (temperature: $10 \pm 0.2^{\circ} \mathrm{C}$; salinity: $10 \pm$ $1 \mathrm{psu}$ ). In both tanks, bottom and walls were covered using light grey tarpaulin. Each tank was equipped with either a stone reef habitat or a sand bottom habitat. Across the study period, each fish was tested twice, once in each habitat. The simulated habitat in each experimental tank alternated between the stone reef habitat and the sand bottom habitat. In both tanks, the respirometry chamber was placed on the bottom in the central part of the tank. The stone reef habitat was created around the respirometry chamber using rocks collected at nearby beaches. Individual rocks were 20-30 cm in diameter and covered the respirometry chamber in 1 layer, creating a cavernous reef often preferred by G. morhua (Tupper \& Boutilier 1997, Kristensen et al. 2017). For the sand bottom habitat, no rocks were added to the experimental tank to mimic an environment with limited benthic complexity.

Prior to respirometry, individual fish were fasted for $48 \mathrm{~h}$ to minimize the post-absorptive state and 


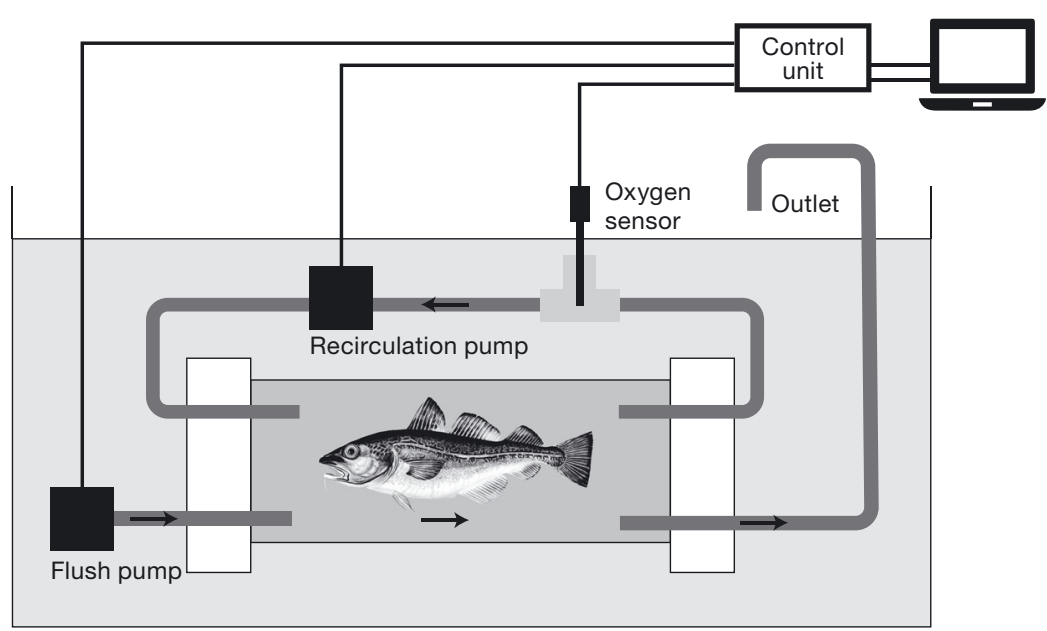

Fig. 1. Experimental setup for measurements of oxygen consumption rate of Atlantic cod Gadus morhua. The respirometry chamber was connected to an intermittent flow respirometry system. The oxygen sensor was located in the recirculating loop. Sampling of each fish lasted $35 \mathrm{~h}: 11 \mathrm{~h}$ of acclimation to the respirometry chamber followed by $24 \mathrm{~h}$ of data collection. Fish were tested in 2 types of simulated habitats (sandy bottom or stone reef) in a random order. The 2 tanks were identical and surfaces were covered with a light grey tarpaulin. The stone reef habitat was created by covering the respirometer chamber with 1 layer of rocks $(20-30 \mathrm{~cm}$ in diameter)

metabolic effects of digestion. Fish were then transferred individually to the respirometry chambers. Each chamber was connected to an intermittent flow respirometry system (Fig. 1) controlled by the Loligo Systems software AutoResp that calculated $\mathrm{MO}_{2}$ ( $\mathrm{mg} \mathrm{O}_{2} \mathrm{~kg}^{-1} \mathrm{~h}^{-1}$ ). Two optical dipping probe oxygen mini sensors (Loligo Systems) were used, one for each respirometry chamber and located in the recirculating loop, in connection with a Witrox 4 oxygen meter (Loligo Systems).

The declining oxygen partial pressure $(\mathrm{kPa})$ inside the respirometry chamber was used to calculate $\mathrm{MO}_{2}$ ( $\mathrm{mg} \mathrm{O}_{2} \mathrm{~kg}^{-1} \mathrm{~h}^{-1}$ ) using the equation:

$$
\mathrm{MO}_{2}=\frac{K V \beta}{M}
$$

where $K$ is the rate of decline $\left(\mathrm{kPa} \mathrm{h}^{-1}\right)$ in oxygen content over time (h) inside the respirometer, $V$ is the volume of the respirometer (l) corrected for the volume of fish, $\beta$ is the solubility of oxygen in the water ( $\mathrm{mg} \mathrm{O}_{2} \mathrm{l}^{-1} \mathrm{kPa}^{-1}$ ), and $M$ is body mass of the fish (kg).

Intermittent flow respirometry was used to sample $\mathrm{MO}_{2}$ for a $35 \mathrm{~h}$ period: $11 \mathrm{~h}$ of acclimation to the respirometry chamber followed by $24 \mathrm{~h}$ of data collection (Fig. 1) (Steffensen 1989, Chabot et al. 2016). The repeated respirometric loops consisted of an 8 min flush period, allowing the total respirometer volume to be flushed 6 times, followed by a 2 min wait period and a 6 min measuring period (i.e. 16 min per loop). Durations of the 3 periods were determined during preliminary testing to ensure (1) that the coefficient of determination $\left(\mathrm{R}^{2}\right)$ always exceeded 0.95 similar to previous studies (Svendsen et al. 2012, Plambech et al. 2013) and (2) that oxygen levels were always $>80 \%$ air saturation inside the respirometry chamber. Microbial respiration was measured before and after each experiment and subtracted from the $\mathrm{MO}_{2}$ (Rodgers et al. 2016).

Juvenile G. morhua are frequently preyed upon by marine mammals and fish. Hence, during the $24 \mathrm{~h}$ data collection, at $15 \mathrm{~h}$, a fusiform simulated predator was pulled once through the water in the experimental tanks. Similar to previous studies (Killen et al. 2012), this was done to simulate a brief presence of a predator. All experiments were performed according to the national guidelines for the care and use of laboratory animals as stated by the Danish Animal Ethics Committee.

Using a paired design, individual fish were tested once in each simulated habitat (stone reef and sand bottom) in the same experimental tank. The order of the tested habitats and fish was randomized. For the individual fish, time between testing in the 2 habitats varied between 4 and $15 \mathrm{~d}$.

For the individual fish, $\mathrm{MO}_{2}$ data were summed across the entire $24 \mathrm{~h}$ period that followed the acclimation period $(11 \mathrm{~h})$. The compiled data were used to compare total metabolic rates over $24 \mathrm{~h}\left(\mathrm{mg} \mathrm{O}_{2} \mathrm{~kg}^{-1}\right.$ $\left[24 \mathrm{~h}^{-1}\right.$ ) between the 2 habitat types (i.e. stone reef and sand bottom). Moreover, for each fish, SMR was calculated using the $10 \%$ method, which provides an SMR estimate based on the average of the lowest $10 \%$ of the measurements, after removal of outliers (i.e. the 5 lowest measurements) as described by Chabot et al. (2016).

Shapiro tests showed that data did not deviate significantly from normal distributions. Hence, paired $t$ tests were applied to test for significant differences in the metabolic rates between the 2 habitats. Specifically, accumulated metabolic rates over $24 \mathrm{~h}\left(\mathrm{mg} \mathrm{O}{ }_{2}\right.$ $\left.\mathrm{kg}^{-1}[24 \mathrm{~h}]^{-1}\right)$ and SMR (mg O $\mathrm{kg}^{-1} \mathrm{~h}^{-1}$ ) were compared between stone reef and sand bottom habitats. Likewise, differences in metabolic responses to predator exposure were evaluated for the 2 habitats by comparing the accumulated metabolic rates over $2 \mathrm{~h}$ after the predator exposure. Accumulated metabolic rates over $24 \mathrm{~h}$, accumulated metabolic rates over $2 \mathrm{~h}$ 
Table 1. Accumulated oxygen consumption rate $\left(\mathrm{MO}_{2} ; \mathrm{mg} \mathrm{O}_{2}\right.$ $\mathrm{kg}^{-1}[24 \mathrm{~h}]^{-1}$ ), mean standard metabolic rate (SMR; $\mathrm{mg} \mathrm{O}$ $\mathrm{kg}^{-1} \mathrm{~h}^{-1}$ ) and the accumulated $\mathrm{MO}_{2}$ over $2 \mathrm{~h}$ following the predator exposure $\left(\mathrm{mg} \mathrm{O}_{2} \mathrm{~kg}^{-1}[2 \mathrm{~h}]^{-1}\right)$ of each tested Atlantic cod Gadus morhua

\begin{tabular}{|c|c|c|c|c|c|c|}
\hline \multirow[t]{2}{*}{ Fish } & \multicolumn{2}{|c|}{$-\mathrm{MO}_{2}$} & \multicolumn{2}{|c|}{$\longrightarrow \mathrm{SMR}-$} & \multicolumn{2}{|c|}{$\begin{array}{c}\mathrm{MO}_{2} \text { after } \\
\text { predator exposure }\end{array}$} \\
\hline & $\begin{array}{l}\text { Stone } \\
\text { reef }\end{array}$ & $\begin{array}{c}\text { Sand } \\
\text { bottom }\end{array}$ & $\begin{array}{l}\text { Stone } \\
\text { reef }\end{array}$ & $\begin{array}{l}\text { Sand } \\
\text { bottom }\end{array}$ & $\begin{array}{c}\text { Stone } \\
\text { reef }\end{array}$ & $\begin{array}{l}\text { Sand } \\
\text { bottom }\end{array}$ \\
\hline 1 & 4094 & 3641 & 135 & 102 & 376 & 390 \\
\hline 2 & 2522 & 4285 & 68 & 95 & 237 & 445 \\
\hline 3 & 1926 & 2740 & 50 & 56 & 166 & 221 \\
\hline 4 & 1980 & 2052 & 57 & 57 & 214 & 192 \\
\hline 5 & 1871 & 3356 & 98 & 53 & 159 & 290 \\
\hline 6 & 1987 & 3380 & 56 & 109 & 291 & 296 \\
\hline 7 & 5057 & 4788 & 89 & 96 & 383 & 611 \\
\hline 8 & 2756 & 3085 & 85 & 94 & 272 & 294 \\
\hline 9 & 2811 & 3349 & 68 & 71 & 286 & 366 \\
\hline 10 & 1327 & 1755 & 37 & 52 & 87 & 151 \\
\hline 11 & 4103 & 4056 & 111 & 113 & 398 & 433 \\
\hline
\end{tabular}

following the predator exposure, and SMR data are presented in Table 1.

The free statistical software R (R 3.5, The R Foundation for Statistical Computing) was used for data analyses. We used a significance level of $\alpha=0.05$, and all values are reported as means \pm SE unless noted otherwise.

\section{RESULTS}

Across the majority $(97.8 \%)$ of the $24 \mathrm{~h}$ sampling period, fish in the stone reef habitat had, on average, reduced metabolic rates (Fig. 2). This pattern was also revealed when comparing the accumulated $\mathrm{MO}_{2}$ values of fish $\left(\mathrm{mg} \mathrm{O} \mathrm{Kg}^{-1}\left[24 \mathrm{~h}^{-1}\right)\right.$ in stone reef and sand bottom habitats, where the accumulated $\mathrm{MO}_{2}$ was significantly lower for fish in stone reef ( $p=0.03$; Fig. 3$)$. Specifically, the mean accumulated $\mathrm{MO}_{2}$ over $24 \mathrm{~h}$ was $2766.7 \pm 352.4$ and $3317.0 \pm 272.8 \mathrm{mg} \mathrm{O}_{2} \mathrm{~kg}^{-1}[24 \mathrm{~h}]^{-1}$ for fish in the stone reef and sand bottom habitat, respectively, showing that fish in the stone reef habitat spent on average $20 \%$ less energy compared to fish in the sand bottom habitat. The SMR data followed the same trend as the accumulated $\mathrm{MO}_{2}$, although statistical analysis revealed no significant differences in mean SMR between fish in the 2 habitats ( $p=0.61$; Fig. 4). Furthermore, when comparing the accumulated metabolic rate over $2 \mathrm{~h}$ after predator exposure, fish in the sand bottom habitat had significantly higher metabolic response compared to fish in reef habitat $(\mathrm{p}=0.013)$.

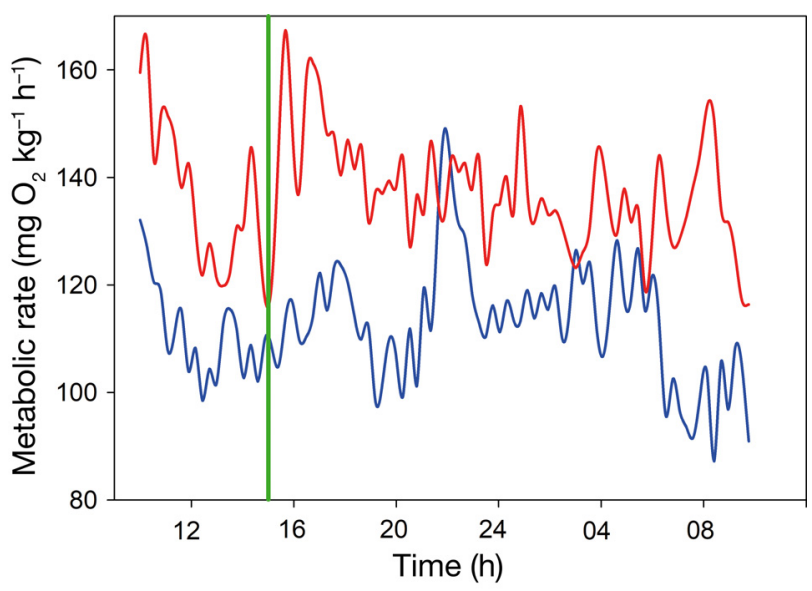

Fig. 2. Mean metabolic rates $\left(\mathrm{mg} \mathrm{O}_{2} \mathrm{~kg}^{-1} \mathrm{~h}^{-1}\right)$ of juvenile Atlantic cod Gadus morhua $(\mathrm{n}=11)$. Data were collected in fish in stone reef (blue line) and sand bottom (red line) habitats over $24 \mathrm{~h}$, after $11 \mathrm{~h}$ of acclimation to the respirometry chamber (Fig. 1). The green line indicates the timing of a brief simulated predator exposure. During $97.8 \%$ of the time, G. morhua in the stone reef habitat exhibited reduced metabolic rate compared to the sand bottom habitat. Measures of variation associated with the plotted mean values have been omitted for clarity

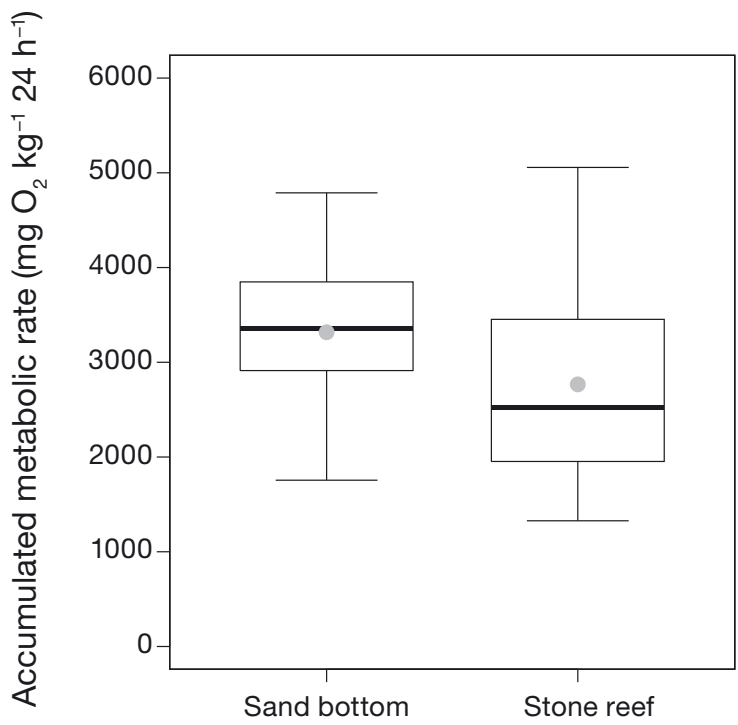

Fig. 3. Accumulated metabolic rate over $24 \mathrm{~h}\left(\mathrm{mg} \mathrm{O}_{2} \mathrm{~kg}^{-1}\right.$ $[24 \mathrm{~h}]^{-1}$ ) in juvenile Atlantic cod Gadus morhua $(\mathrm{n}=11)$. Data were collected in fish in stone reef and sand bottom habitats over $24 \mathrm{~h}$, after $11 \mathrm{~h}$ of acclimation to the respirometry chamber (Fig. 1). G. morhua in the stone reef habitat exhibited reduced average metabolic rate compared to fish in the sand bottom habitat $(\mathrm{p}=0.03)$. Solid line: median; grey dot: mean; box: interquartile range, where bottom and top are 25th and 75th percentiles, respectively; whiskers: max and min observations 


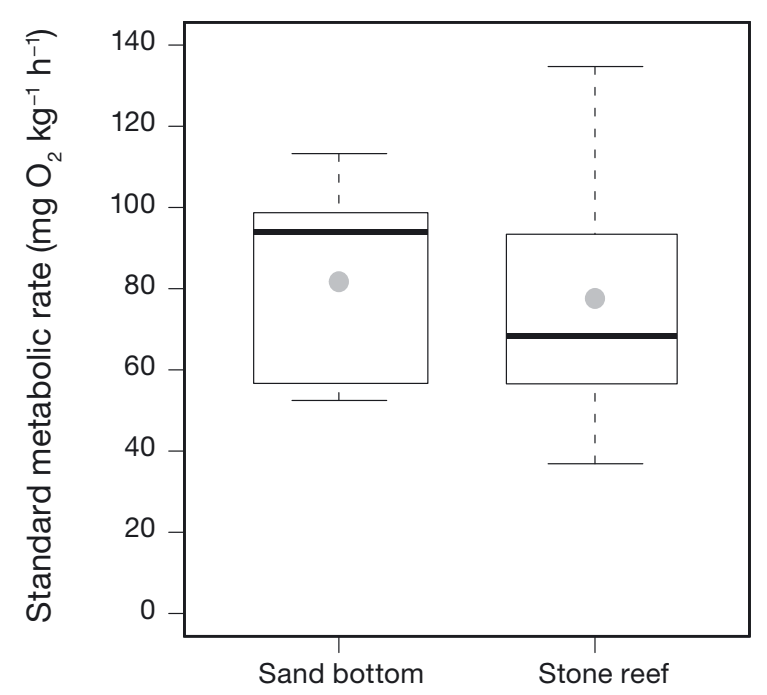

Fig. 4. Mean standard metabolic rate $\left(\mathrm{SMR}_{;} \mathrm{mg} \mathrm{O}_{2} \mathrm{~kg}^{-1} \mathrm{~h}^{-1}\right)$ in juvenile Atlantic cod Gadus morhua $(\mathrm{n}=11)$, calculated using the $10 \%$ method after the 5 lowest measurements were removed as outliers (Chabot et al. 2016). Data were collected in fish in stone reef and sand bottom habitats over $24 \mathrm{~h}$, after $11 \mathrm{~h}$ of acclimation to the respirometry chamber (Fig. 1). SMR data revealed no statistical differences between the 2 habitats $(p=0.61)$. Box plot parameters as in Fig. 3

\section{DISCUSSION}

This study shows that the energy use of Atlantic cod Gadus morhua is affected by the surrounding habitat. Specifically, the accumulated $\mathrm{MO}_{2}$ data revealed that G. morhua save energy (about 20\%) when occupying a stone reef habitat compared to a sand bottom habitat. Accordingly, fish using a sand bottom habitat have an energetic disadvantage that may result in decreased growth rates. The results also suggest that predator encounters are energetically less costly in reef habitats. Although a similar pattern was observed in SMR (i.e. fish in the sand habitat showed a tendency towards higher SMR than fish in the reef habitat), differences were not statistically significant between the 2 habitats. The mean accumulated $\mathrm{MO}_{2}$ over $24 \mathrm{~h}$ includes SMR as well as processes that elevate the oxygen consumption rate above SMR, such as spontaneous activity and stress evoked by predator exposure. The effects of habitats on $\mathrm{MO}_{2}$ may be caused by different activity levels, excitement, diel patterns in energy use etc. (Chabot et al. 2016). The present SMR values for G. morhua are within the range of previously reported values for this species at equivalent temperatures (Soofiani \& Hawkins 1982, Claireaux et al. 2000, Plambech et al. 2013).
The mechanisms underpinning increased fish production in reef habitats remain widely debated, including suggestions of enhanced provision of food on reefs, availability of shelters leading to reduced predation, reduced fishing mortality, in addition to the provision of zones with reduced water motion and current speed, where fish can stay and hence reduce energy related to swimming (Emery et al. 2006, Claisse et al. 2014, Champion et al. 2015). Here, we show that the energy demand of G. morhua is reduced when the fish spend time in reef habitats, thus providing an important new understanding of the mechanisms underpinning the increased productivity observed on reefs. More specifically, our results demonstrate that the fish in reef habitats on average exhibited a $20 \%$ reduction in their daily energy budget as compared to fish in sandy, open habitats. The higher energy use in the less structurally complex habitat may reflect that the fish need to be more attentive to minimize the higher predation risk (Gotceitas \& Brown 1993, Tupper \& Boutilier 1995), potentially including elevated spontaneous activity and excitement (Chabot et al. 2016). Likewise, our results suggest that predator encounters are energetically more costly in less structurally complex habitats. A lower daily energy demand on reefs may allow the individual fish to allocate more resources to somatic or gonadal growth. Importantly, fish in better condition generally have higher reproductive output (Kjesbu et al. 1991, Rätz \& Lloret 2003), indicating potential for sustaining a higher exploitation rate (Rätz \& Lloret 2003). Juvenile G. morhua furthermore benefit in terms of higher survival in structurally complex habitats, as these habitats provide shelter availability against predation as compared to sandy habitats (Gotceitas \& Brown 1993, Tupper \& Boutilier 1995, Lindholm et al. 1999). Notably, however, production and attraction are ends of a spectrum on which most reefs operate (Cresson et al. 2019). In other words, there will be variable contributions of fish aggregations and new production to observed changes in biomass of fish, depending on the functional position of the species at the reef and the lifestyle of the fish, e.g. whether it is a sedentary benthic or highly mobile species (Reubens et al. 2013, Cresson et al. 2019, Roa-Ureta et al. 2019). Although the present study has revealed that energy savings at reefs may promote increased production of $G$. morhua, it is also known that boulder reef restoration results in higher site fidelity and prolonged residence time in the area for this species (Kristensen et al. 2017), pointing towards the aggregation end of the spectrum. Collectively, these findings highlight the 
importance of preserving temperate reef habitats to support fish populations.

In many parts of the world, reefs support millions of people who depend on natural resources as a source of food and income (White et al. 2000, Cesar et al. 2003). However, degradation of reefs continues, and structurally complex habitats are becoming rarer across many marine environments (Pandolfi et al. 2003, Airoldi et al. 2008). Irrespective of the position of a particular reef on the aggregation-production spectrum, its degradation is likely to have profound ecological, social and economic impacts. This is also highlighted by the fact that reefs are some of the most diverse marine ecosystems (Roberts et al. 2002), and their degradation may hence cause loss of biodiversity (Jones et al. 2004). Consequently, protection of reefs is important to maintain productive marine ecosystems (Pratchett et al. 2014). The present results show a link between habitat complexity (stone reef habitat versus sand habitat) and energetic demands of G. morhua, supporting that stone reefs facilitate increased production of this species. However, fish community composition varies among reefs, affected by several factors including architectural complexity, reef size, abiotic conditions and fish dispersal abilities (Charbonnel et al. 2000, Champion et al. 2015, Cresson et al. 2019). This highlights the importance in future research of considering species-specific responses to habitat complexity to accurately describe the functioning of reefs, both natural and artificial.

Acknowledgements. We thank Hans Hansen and Sebastian Bøe for their technical support and for constructing the experimental set-up. We also thank John F. Steffensen and Emil A. F. Christensen for the availability of the 2 respirometry chambers; Anne Folkvard for graphical assistance; and the anonymous reviewers who provided constructive input and helped improve the final version of the paper.

\section{LITERATURE CITED}

Airoldi L, Balata D, Beck MW (2008) The gray zone: relationships between habitat loss and marine diversity and their applications in conservation. J Exp Mar Biol Ecol 366:8-15

Ambrose R, Swarbrick S (1989) Comparison of fish assemblages on artificial and natural reefs off the coast of southern California. Bull Mar Sci 44:718-733

Australian Government (1975) Great barrier reef marine park act 1975. www.legislation.gov.au/Details/C2017C00279 (accessed 6 August 2018)

Baine M (2001) Artificial reefs: a review of their design, application, management and performance. Ocean Coast Manage 44:241-259

Bohnsack JA, Sutherland DL (1985) Artificial reef research: a review with recommendations for future priorities. Bull Mar Sci 37:11-39
Brickhill MJ, Lee SY, Connolly RM (2005) Fishes associated with artificial reefs: attributing changes to attraction or production using novel approaches. J Fish Biol 67:53-71

Cesar H, Burke L, Pet-Soede L (2003) The economics of worldwide coral reef degradation. www.wwf.or.jp/activities/lib/ pdf_marine/coral-reef/cesardegradationreport100203.pdf

Chabot D, Steffensen JF, Farrell AP (2016) The determination of standard metabolic rate in fishes. J Fish Biol 88:81-121

Champion C, Suthers IM, Smith JA (2015) Zooplanktivory is a key process for fish production on a coastal artificial reef. Mar Ecol Prog Ser 541:1-14

* Charbonnel E, Francour P, Harmelin JG, Ody D, Bachet F (2000) Effects of artificial reef design on associated fish assemblages in the Côte Bleue marine park (Mediterranean Sea, France). In: Jensen A, Collins K, Lockwood AP (eds) Artificial reefs in European seas. Springer, Dordrecht, p 365-377

Claireaux G, Webber DM, Lagardère JP, Kerr SR (2000) Influence of water temperature and oxygenation on the aerobic metabolic scope of Atlantic cod (Gadus morhua). J Sea Res 44:257-265

Claisse JT, Pondella DJ, Love M, Zahn LA, Williams CM, Williams JP, Bull AS (2014) Oil platforms off California are among the most productive marine fish habitats globally. Proc Nat Acad Sci 111:15462-15467

Cresson P, Le Direach L, Rouanet E, Goberville E, Astruch P, Ourgaud M, Harmelin-Vivien M (2019) Functional traits unravel temporal changes in fish biomass production on artificial reefs. Mar Environ Res 145:137-146

Dahl K, Støttrup JG, Stenberg C, Berggreen UC, Jensen JH (2016) Best practice for restoration of stone reefs in Denmark (Codes of Conduct). Tech Rep 91. DCE - Danish Centre for Environment and Energy, Aarhus University, Roskilde

* De'ath G, Fabricius KE, Sweatman H, Puotinen M (2012) The 27-year decline of coral cover on the Great Barrier Reef and its causes. Proc Natl Acad Sci USA 109:17995-17999

Demartini EE, Barnett AM, Johnson TD, Ambrose RF (1994) Growth and production estimates for biomass-dominant fishes on a southern California artificial reef. Bull Mar Sci 55:484-500

Emery BM, Washburn L, Love MS, Nishimoto MM, Ohlmann JC (2006) Do oil and gas platforms off California reduce recruitment of bocaccio (Sebastes paucispinis) to natural habitat? An analysis based on trajectories derived from high-frequency radar. Fish Bull 104:391-400

* Gotceitas V, Brown JA (1993) Substrate selection by juvenile Atlantic cod (Gadus morhua): effects of predation risk. Oecologia 93:31-37

Gotceitas V, Fraser S, Brown JA (1995) Habitat use by juvenile Atlantic cod (Gadus morhua) in the presence of an actively foraging and non-foraging predator. Mar Biol 123:421-430

* Granneman JE, Steele MA (2014) Fish growth, reproduction, and tissue production on artificial reefs relative to natural reefs. ICES J Mar Sci 71:2494-2504

*Gossman GD, Jones GP, Seaman WJ Jr (1997) Do artificial reefs increase regional fish production? A review of existing data. Fisheries 22:17-23

Jones GP, McCormick MI, Srinivasan M, Eagle JV (2004) Coral decline threatens fish biodiversity in marine reserves. Proc Natl Acad Sci USA 101:8251-8253

Killen SS, Marras S, Ryan MR, Domenici P, McKenzie DJ (2012) A relationship between metabolic rate and risk- 
taking behaviour is revealed during hypoxia in juvenile European sea bass. Funct Ecol 26:134-143

Kjesbu OS, Klungsøyr J, Kryvi H, Witthames PR, Walker MG (1991) Fecundity, atresia, and egg size of captive Atlantic cod (Gadus morhua) in relation to proximate body composition. Can J Fish Aquat Sci 48:2333-2343

Kristensen LD, Støttrup JG, Svendsen JC, Stenberg C, Højbjerg Hansen OK, Grønkjær P (2017) Behavioural changes of Atlantic cod (Gadus morhua) after marine boulder reef restoration: implications for coastal habitat management and Natura 2000 areas. Fish Manag Ecol 24:353-360

KLindholm JB, Auster PJ, Kaufman LS (1999) Habitat-mediated survivorship of juvenile (0-year) Atlantic cod Gadus morhua. Mar Ecol Prog Ser 180:247-255

Lotze HK, Lenihan HS, Bourque BJ, Bradbury RH and others (2006) Depletion, degradation, and recovery potential of estuaries and coastal seas. Science 312:1806-1809

Lundsteen S, Dahl K, Tendal OS (2008) Biodiversity on boulder reefs in central Kattegat. BALANCE Interim Rep 15. https://balance-eu.org/xpdf/balance-interim-report-no15.pdf

Millidine KJ, Armstrong JD, Metcalfe NB (2006) Presence of shelter reduces maintenance metabolism of juvenile salmon. Funct Ecol 20:839-845

Nakamura M (1985) Evolution of artificial fishing reef concepts in Japan. Bull Mar Sci 37:271-278

Nelson JA (2016) Oxygen consumption rate $v$. rate of energy utilization of fishes: a comparison and brief history of the two measurements. J Fish Biol 88:10-25

Norin T, Mills SC, Crespel A, Cortese D, Killen SS, Beldade $R$ (2018) Anemone bleaching increases the metabolic demands of symbiont anemonefish. Proc R Soc B 285: 20180282

Pandolfi JM, Bradbury RH, Sala E, Hughes TP and others (2003) Global trajectories of the long-term decline of coral reef ecosystems. Science 301:955-958

Plambech M, Van Deurs M, Steffensen JF, Tirsgaard B, Behrens JW (2013) Excess post-hypoxic oxygen consumption in Atlantic cod (Gadus morhua). J Fish Biol 83: 396-403

Polovina JJ (1989) Artificial reefs: nothing more than benthic fish aggregators. Calif Coop Ocean Fish Invest Rep 30:37-39

* Pratchett MS, Hoey AS, Wilson SK (2014) Reef degradation and the loss of critical ecosystem goods and services provided by coral reef fishes. Curr Opin Environ Sustain 7 : 37-43

Priede IG (1985) Metabolic scope in fishes. In: Tytler P, Calow $P$ (eds) Fish energetics: new perspectives. Springer Netherlands, Dordrecht, p 33-64

Rätz HJ, Lloret J (2003) Variation in fish condition between Atlantic cod (Gadus morhua) stocks, the effect on their productivity and management implications. Fish Res 60: 369-380

Editorial responsibility: Jana Davis, Annapolis, Maryland, USA
Reubens JT, Braeckman U, Vanaverbeke J, Van Colen C, Degraer S, Vincx M (2013) Aggregation at windmill artificial reefs: CPUE of Atlantic cod (Gadus morhua) and pouting (Trisopterus luscus) at different habitats in the Belgian part of the North Sea. Fish Res 139:28-34

* Roa-Ureta RH, Santos MN, Leitão F (2019) Modelling longterm fisheries data to resolve the attraction versus production dilemma of artificial reefs. Ecol Model 407:108727

* Roberts CM, McClean CJ, Veron JEN, Hawkins JP and others (2002) Marine biodiversity hotspots and conservation priorities for tropical reefs. Science 295:1280-1284

* Rodgers GG, Tenzing P, Clark TD (2016) Experimental methods in aquatic respirometry: the importance of mixing devices and accounting for background respiration. J Fish Biol 88:65-80

Ross SD, Andreasen H, Andersen NG (2016) An important step towards accurate estimation of diet composition and consumption rates for the harbor porpoise (Phocoena phocoena). Mar Mamm Sci 32:1491-1500

Savenkoff C, Castonguay M, Chabot D, Fréchet A, Hammill MO, Morissette L (2006) Main prey and predators and estimates of mortality of Atlantic cod (Gadus morhua) in the northern Gulf of St. Lawrence during the mid-1980s, mid-1990s, and early 2000s. Can Tech Rep Fish Aquat Sci 2666:1-32

* Smith JA, Lowry MB, Champion C, Suthers IM (2016) A designed artificial reef is among the most productive marine fish habitats: new metrics to address 'production versus attraction'. Mar Biol 163:188

Soofiani NM, Hawkins AD (1982) Energetic costs at different levels of feeding in juvenile cod, Gadus morhua L. J Fish Biol 21:577-592

* Steffensen JF (1989) Some errors in respirometry of aquatic breathers: how to avoid and correct for them. Fish Physiol Biochem 6:49-59

Svendsen JC, Steffensen JF, Aarestrup K, Frisk M, Etzerodt A, Jyde M (2012) Excess posthypoxic oxygen consumption in rainbow trout (Oncorhynchus mykiss): recovery in normoxia and hypoxia. Can J Zool 90:1-11

The Council of the European Communities (2013) Council Directive 92/43/EEC of 21 May 1992 on the conservation of natural habitats and of wild fauna and flora. Off J Eur Commun L 269:1-15

* Thrush SF, Dayton PK (2002) Disturbance to marine benthic habitats by trawling and dredging: implications for marine biodiversity. Annu Rev Ecol Syst 33:449-473

* Tupper M, Boutilier RG (1995) Effects of habitat on settlement, growth, and postsettlement survival of Atlantic cod (Gadus morhua). Can J Fish Aquat Sci 52:1834-1841

* Tupper M, Boutilier RG (1997) Effects of habitat on settlement, growth, predation risk and survival of a temperate reef fish. Mar Ecol Prog Ser 151:225-236

*White AT, Vogt HP, Arin T (2000) Philippine coral reefs under threat: the economic losses caused by reef destruction. Mar Pollut Bull 40:598-605

Submitted: April 11, 2019; Accepted: November 7, 2019 Proofs received from author(s): January 13, 2020 